\title{
肝機能に及ほすAcrifuran の影響
}

\author{
第 2 編 \\ 肺結核患者の肝機能に及汪す Acrifuran の影響
}

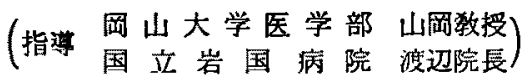

蔵田泰郎

[昭和 33 年 1 月 10 日受稿]

\section{結}

Furan 誘導体は，1923年 Mcguigan1)の報告以来 研究の対象になつていたが, 1944 年 Dodd \& Stillman2) K依り Furacin が合成されるまでは，毒性 が强いので実用価值がないものとされていた，我国 です1946年西海枝㺕挼3)等に依り，Dodd 等とは全 く別個に Furacin 及びその誘望体が合成され，そ れ以来各種の誘導体が相次いで発表せられて，その 薬学的作用敒関する研究も少くない. 今回寺田医学 博士より，Furan の新誘導体たる Acrifuran (3.6Diamino-Furfurol-10 Methyl-Acridinium Chloride) を入取する機会を得た。のでこれる先に第 1 編で

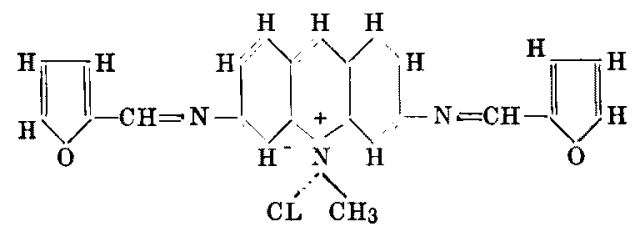

旰機能検查を行つた肺結核悲者55名に試用し，その 影響を見ることにした。

\section{実 酫方 法}

\section{1.実伢対象}

第 1 編に於て肝機能怡查を行つた，肺結核患者55 名である。

\section{2.实施方法}

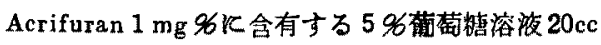
を，1日1回30日間連続静注し，注射周始前及び終 了後飞於いて，体温，体重，食挴，咳濑，喀痰，結 核花，喀血，盗汗，肩凝，不眠及び赤沈等の臨床症 狀, 更に赤血球数，血色菜量，白血球数及びその百 分率等の血液所見に就て，比較検討を試み，また䏦
譏能に及ほす影響を観察した。

3. 肝機能検查法

第 1 編洞し。

\section{実赫成綡並ひに考按}

1. 跕床症狀に対する影鿄

1. 1) 体温

有熱者は 34 名で何れも $38^{\circ} \mathrm{C}$ までのものであつた が, 可熱となつた者11名、下降した者 3 名，その他 不変15名と上昗 5 名とで，重症有熱者 6 名の内下降 1 名不変 3 名及び上界 2 名であつた。

1. 2)

$2.5 \mathrm{~kg}$ 以上增加して標準体重に達するかてれ以上 になつた者は, 轻症の 3 名と中等症の 2 名の都合 5 名で, $2.5 \mathrm{~kg}$ 以上増加したが標準体重に達しなから た者は，柽症の3名と中符症の3名及び重症の 1 名 の都合 7 名であつた：また不変若くは体重の增加が $2.5 \mathrm{~kg}$ K達しなからた者は43名で, 減少した者はな かつ大.

1.3）食慾

注射前食照不振を訴えていた16名の者は，病型の 如何を問わず何れも食䓡殴盛となり，不振とまでは 行かぬ20名も，著しく食䓡が增進した。

1.4) 咳嗽

始め咳濑を訴えていた25名に於て，漸次減少した ものは18名で，その内軽症者の8 名では遂全く消 失し, 残りの不変 7 名は, 総て重症型であつた.

1.5) 喀痰 始め喀痰のあつた者25名の内，漸次减少した者39 名で，その内11名には全く消失した，他に不変の者 3 名と增加した者の 5 名があつたが，これ等は何れ も重症型であつた。

1. 6) 結核菌 
始め䀩痰中に結核获の隄性であつた者は36名であ つたが，秋抹陰性となつた者は中等症の 2 名，减少 した者は重症の3名に見られ，その他不変の29名と 增覀が中等症と重症に各 1 名おつた。

1. 7) 喀血

始め喀血を訴えていた者は 5 名で，注射終了後す 尚同一訴えのある者は1名，他の者は注射持続中並 びにその後に於ても，喀血を見ることはなかつた。

1. 8) 盗汗

始め盗汗のあつた者 4 名で，内 3 名では注射持続 中飞消失し，重症型の1例では不变であつた。

1. 9) 肩凝

始め冏凝の訴立があつた者12名で，その内11名は 注射持続中全く消失し，中等症の 1 名のみ不変て あつた。

1. 10）不眠

始め不眠を訴えていた者20名で，内注射持続中に 訴光の全く消失した者19名で，重症型の 1 例に不変 であつた.

\section{11）赫}

始め促進を見せた 36 名に於て，後正常よりも更に 遅延した者軽症の 1 名，幾分なりとも遅延して来た 者軽症の 1 名と中等症の 2 名及び重症の 3 名の都合 6 名, 不変 19 名以軽症 3 名と中等症 5 名及び重症の 11名から成り，促進した者は軽症 4 名と中等症 3 名 及び重症の 3 名の都合10名であつた。

以上飞依り本剂注射後には，病型の如何に拘らず， 気分の爽快中食愁の增進，盗汗や不眠及び肩凝等， 結核患者《多く見る神経性自覚症狀が好転し，従つ て体重の增加する者が多く，主として軽症や中等症 K，喀血や咳濑喀痰の減少及び体温の下降等が見ら れたが，結核菌の排出や赤沈には改善の䟢が見られ なかつた。

2. 血液所見比対する影篦

J. Leitner(4)，加藤5)筒井6)，小林7)及(゙合金8)等飞 れば，肺結核患者の血液像中最も臨床的価值を有す るの恃，赤血球数と血色素並びそ白血球，その中で も好中球や淋巴球及び単球の動向であると言う．依 つて主としてこれ等の項目に付き検討した。

2. 1) 赤血球

本剂の注射に依り赤血球の形態や染色能の变化, 赤芽球及び核の残䯓を有する赤血球の出現等は認め られなかつた，小林，倉金，小宮9) 及び永井10)等飞 依れば，肺結核症で赤血球数の減少は，予後不良の 微であると言い，佐守11は赫血球数の増湍は，赤沈

速度の漣速と相当な負の相関を持ち，赤沈反匛の本 热としての赤血球数の意義は，大であると述べてい る. 日本人健康男女の赤血球数て就ては，倉金，田 中12)，吉橋(3)及び大関14)等に依り発表されているが， 今小宮の報告飞従い，病的減少と正常及び病的增加 に区別して見た，すると第1表の榢になり，本剂注

第 1 表 Acrifuran 注射飞依る赤血球数の変動

\begin{tabular}{|c|c|c|c|c|c|}
\hline 庐 & 型 & \multicolumn{2}{|c|}{ 検查時期|病的诚少 } & \multirow{2}{*}{$\frac{\text { 正 常 }}{9}$} & \multirow{2}{*}{$\frac{\text { 病的增加 }}{0}$} \\
\hline \multirow{2}{*}{ 整 } & \multirow{2}{*}{ 症 } & 前 & 2 & & \\
\hline & & 後 & 0 & 11 & 0 \\
\hline \multirow{2}{*}{\multicolumn{2}{|c|}{ 中等 症 }} & 前 & 2 & 21 & 0 \\
\hline & & 後 & 3 & 20 & 0 \\
\hline & \multirow{2}{*}{ 症 } & 前 & 2 & 13 & 0 \\
\hline & & 後 & 4 & 11 & 0 \\
\hline \multirow{2}{*}{ 合 } & \multirow{2}{*}{ 計 } & 前 & 6 & 43 & 0 \\
\hline & & 後 & 7 & 42 & 0 \\
\hline
\end{tabular}

射後柽店では病的減少が 2 名減り，中等症では 1 名 の重症では 2 名の增加となり，病的增加を示し又は 病的增加を示すに至つた者はなかつた，而して何れ の場合に於てもこれを推計学的に見ると，有意の差 は望められなかつた。

\section{2) 血色素量}

全金依依結核症飞於て血色素量の減少は，病 巣が広汎になる程，また病梦が重症に傾く程，及び 増殖型より參出型に移る程著明になる傾向があると 言い，Grawitz15) と Naegeli16)及び小林等も同様の 報告をしている，日本人の血色素量に就いては，田

第 2 表 Acrifuran 注射飞依る血色素量の変動

\begin{tabular}{|c|c|c|c|c|c|}
\hline 病 & 型 & 検査時， & 的诚少 & 正 常 & 病的增加 \\
\hline \multirow{2}{*}{ 柽 } & \multirow{2}{*}{ 症 } & 前 & 2 & 9 & 0 \\
\hline & & 後 & 0 & 11 & 0 \\
\hline \multirow{2}{*}{\multicolumn{2}{|c|}{ 中等 症 }} & 前 & 2 & 21 & 0 \\
\hline & & 後 & 3 & 20 & 0 \\
\hline \multirow{2}{*}{ 重 } & \multirow{2}{*}{ 症 } & 前 & 2 & 13 & 0 \\
\hline & & 後 & 4 & 11 & 0 \\
\hline \multirow{2}{*}{ 合 } & \multirow{2}{*}{ 計 } & 前 & 6 & 43 & 0 \\
\hline & & 後 & 7 & 42 & 0 \\
\hline
\end{tabular}


中，吉橋，倉金及び大関等が発表しているが，小宮 に従いこれを病的減少と正常及び病的增加に区別し て見た。すると本剂注射後怪症で病的减少者が 2 名 娍り正常者は 2 名增加し，中等症では病的减少者 1 名增加正常者 1 名减少となり, 重症飞於ては病的減 少者 2 名増加と正常者 2 名の减少となつたか，何れ の場合共推計学的には，有意の差を認めるとこが出 来なかつた。

2. 3) 白血球数

合金飞依机紹核症飞於て白血球は，病坚の広汎 な程また渗出型で進行性なるの程增加の傾向に在る と述へ，早川，颎尾17)，筒井及び小林等も同樣の報 告をしている，日本人の白血球数に就ては，田中， 吉橋，大関及び粟谷川等の発表があるが，小宮の分 別法飞彷い病的減少と正常及び病的增加にわけて観 察すると，本剂注射後には軽症では，病的減少者が 3 名增して正常者は 2 名減り，病的增加の 1 名が正 常者に復した，然し中等症及び重症では，これと言 ろ変動はなからた。推計学的倠察すると、軽症者 のそれも有密の差とは認め難い。

第 3 表 Acrifuran 注射に依る白血球数の変動

\begin{tabular}{|c|c|c|c|c|c|}
\hline 病 & 型 & 娭查時期 & 病的減少 & 正 常 & 病的増扣 \\
\hline \multirow{2}{*}{ 軽 } & \multirow{2}{*}{ 症 } & 前 & 0 & 11 & 1 \\
\hline & & 後 & 3 & 9 & 0 \\
\hline \multirow{2}{*}{ 中 } & \multirow{2}{*}{ 症 } & 前 & 0 & 23 & 0 \\
\hline & & 後 & 0 & 23 & 0 \\
\hline \multirow{2}{*}{ 重 } & \multirow{2}{*}{ 泟 } & 前 & 0 & 15 & 0 \\
\hline & & 後 & 0 & 15 & 0 \\
\hline \multirow{2}{*}{ 合 } & \multirow{2}{*}{ 計 } & 前 & 0 & 49 & 1 \\
\hline & & 後 & 3 & 47 & G \\
\hline
\end{tabular}

2. 4) 白血球百分率

本剂を注射して，白血球の退行恋性を来したり， 幼若型や形質細胞及び内皮細盷の出現は，これを認 めることが出来なかつた。

\section{4) 1. 好中球}

結核症に於て好中球の比率は, 型で進行性の もの程高いことが, 倉金, Arneth18), Naegeli, Schwermann19), Appelbaum, Hermann20), Blumenfeld21), Glöel, Stegen, 草間22), 鉿木23)及び永井等 から埌告されている，日本人の好中球百分率飞つい ては，吉岡，大関及び栗谷川等の発表があるが，今
第 4 表 Acrifuran 注射に依る好中球百分 率の変動

\begin{tabular}{|c|c|c|c|c|c|}
\hline 筑 & 型 & 検查時期 & 病的酸少 & 正 常 & 病的增加 \\
\hline \multirow{2}{*}{ 鉥 } & \multirow{2}{*}{ 症 } & 前 & 0 & 11 & 0 \\
\hline & & 後 & 0 & 11 & 0 \\
\hline \multirow{2}{*}{ 中 等 } & \multirow{2}{*}{ 症 } & 前 & 1 & 17 & 4 \\
\hline & & 後 & 0 & 22 & 0 \\
\hline \multirow{2}{*}{ 重 } & \multirow{2}{*}{ 症 } & 前 & 0 & 11 & 4 \\
\hline & & 後 & 0 & 11 & 4 \\
\hline \multirow{2}{*}{ 合 } & \multirow{2}{*}{ 計 } & 前 & 1 & 39 & 8 \\
\hline & & 後 & 0 & 44 & 4 \\
\hline
\end{tabular}

小宮の分別法に從い観察すると，軽症では正常者の みで変化なく，中等症では病的增加の 4 名と病的娍 少の 1 名が正常者に復し, 重症で族的增加の4名 に於て不変であつた，従つてこれを綜合的に胃れば， 推計学的に有意な影繁とは認められない.

\section{4) 1. 1. 核左方推移}

結核症に於ける核左方推移は，Leitner に依れば 非活動性のものKは極めて稀であるか，活動性結核 では9096に認めると言い，木原2A》は他の擥床諸症狀 に㷇儿先んじて現われ，症狀経過を敏感卒直に表現 し，徒つて活動泩病巣の早期発見や症狀経過の観察 及び治療方針の確立に，重要であると述へている. また成田28)は核左方推敖の程度が患者の中毒症狀と 平行し，症狀の增恶と共に高度となると言つている

第 5 表 Acrifuran 江射に依る核左方推移 の翏動

\begin{tabular}{|c|c|c|c|c|c|c|}
\hline \multirow{2}{*}{ 病 型 } & \multirow{2}{*}{$\begin{array}{l}\text { 模查 } \\
\text { 㭙期 }\end{array}$} & \multicolumn{2}{|r|}{ 核 } & \multicolumn{2}{|r|}{ 移 } & \multirow[b]{2}{*}{ 最高度 } \\
\hline & & 正常 & 柽度 & 中等度 & 高度 & \\
\hline \multirow{2}{*}{ 軽 症 } & 前 & 4 & 5 & 2 & 0 & 0 \\
\hline & 後 & 8 & 3 & 0 & 0 & 0 \\
\hline \multirow{2}{*}{ 中等症 } & 前 & 10 & 4 & 1 & 4 & 2 \\
\hline & 後 & 11 & 4 & 3 & 2 & 1 \\
\hline \multirow{2}{*}{ 重 症 } & 前 & 1 & 3 & 4 & 5 & 2 \\
\hline & 後 & 4 & 1 & 1 & 6 & 3 \\
\hline \multirow{2}{*}{ 合 計 } & 前 & 15 & 12 & 7 & 9 & 4 \\
\hline & 後 & 23 & 8 & 4 & 8 & 4 \\
\hline
\end{tabular}


が，山内汭，小山26)及び倉金等は，発病に伴つて起 つた核左方推移か，病㹜の悪化之共飞恒常的に整減 すると報告している，核左方推移の分別化は，之れ を始めて提唱した Arneth2)や Schilling 及び杉山 等の方法があるが，山内28のの方法行従つて分別して みると，本剂注射後核左方推移山，軽症では柽度及 び中等度の各 2 例が娍少して正常が 4 例堌加し，ま た中等症では最高度の 1 例と高度の 2 例が娍少する に反して，中等度の 2 例と正常の 1 例が増加した。 重症に於ては最高度と高度の各 1 例が增加し，中等 度の 3 例之軽度の 2 例が減少して, 正常は 3 例の增 加となつた．然しこれ等を綜合的に判断すると，本 剂の注射前後に於て推計学的な有意の差を見出し得 なからた。

2. 4) 2. 淋巴球

合金, Arneth, Bergels, Naegeli 及 びLeiner等 は，結核症に於て病紧が拡大して出型で進行性に なると，淋巴球の百分率が減少する傾向にあると述 べている．日本人の淋巴球百分率については，倉金、 吉橋，大関及び栗谷川等の発表があるが，小宫に従 つて病的減少と正常及び病的增加に分別して見ると， 本剂注射挠の淋巴球百分率は，柽症では影響なく中 等症ては病的旗少及び病的增加加各 1 例增加し，正

第 6 表 Acrifuran 注射飞依る淋巴球百分 率の変動

\begin{tabular}{|c|c|c|c|c|c|}
\hline 病 & 型 & 娭查時斯 & 的晟少 & 正 常 & |病的增加 \\
\hline \multirow{2}{*}{ 㹩 } & \multirow{2}{*}{ 症 } & 前 & 0 & 11 & 0 \\
\hline & & 後 & 0 & 11 & 0 \\
\hline \multirow{2}{*}{ 中 } & \multirow{2}{*}{ 症 } & 前 & 4 & 18 & 0 \\
\hline & & 後 & 5 & 16 & 1 \\
\hline \multirow{2}{*}{ 重 } & \multirow{2}{*}{ 症 } & 前 & 6 & 9 & 0 \\
\hline & & 後 & 5 & 10 & 0 \\
\hline \multirow{2}{*}{ 今A } & \multirow{2}{*}{ 計 } & 前 & 10 & 38 & 0 \\
\hline & & 後 & 10 & 37 & 1 \\
\hline
\end{tabular}

常は 2 例の減少となつた。 また重症では病的減少の 1 例隇少正常の 1 例堌加となつた. 然しこれ等を綜

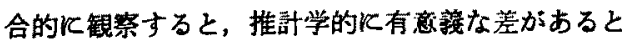
は思われなかつた。

\section{4) 3. 単球}

Leitner，Krause29)，Sabien30）倉金及び小山等に 依れば，結核症の軽重と单球の消長との関には常に
密接な関係があり，重症となるにつれて単球の增加 するのが原則であると述べている，日本人の単球百 分染汇ついては，吉橋，大関、栗谷川及び合金等の 報告があるが，小宮に胣つて病的減少と正常及び病

第 7 表 Acrifuran 注射飞依る単球百分率 の変動

\begin{tabular}{|c|c|c|c|c|c|}
\hline 病 & 型 & 検查洔期 & 病的城少 & 正 常 & 病的增加 \\
\hline \multirow{2}{*}{ 艃 } & \multirow{2}{*}{ 症 } & 前 & 2 & 8 & 1 \\
\hline & & 後 & 3 & 8 & 0 \\
\hline \multirow{2}{*}{ 中 } & \multirow{2}{*}{ 症 } & 前 & 2 & 16 & 3 \\
\hline & & 後 & 1 & 17 & 3 \\
\hline \multirow{2}{*}{ 重 } & \multirow{2}{*}{ 症 } & 前 & 0 & 14 & 1 \\
\hline & & 後 & 1 & 12 & 2 \\
\hline \multirow{2}{*}{ 合 } & \multirow{2}{*}{ 計 } & 前 & 4 & 38 & 5 \\
\hline & & 後 & 5 & 37 & 5 \\
\hline
\end{tabular}

的增加化分別すると，軽症では病的增加の 1 例が減 少して病的減少の 1 例が增加し，中等症では病的減 少の 1 例が減少正常の 1 例加增加した。 また重症で は病的减少が 1 例增加し平常か 1 例堿少した，然し これを綜合的《見ると，推計学的に有意の差を認め 得なかつた。

以上飞依り本剂を注射すると，軽症では赤血球数 や血色素舅は增加の傾向に在り，白血球数は減少の 傾向好中球は正常倠仁維持され，核左方推移は減少 の傾向を示し，尚また淋巳球は正常值のまま単球は 減少の傾向て，病勢と関係のある血液像には，多少 とも好影翌を与えている樣に思われる，中等症で，

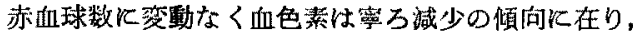
白血球数は正常值飞維持されるが，好中球及び核左 方推移は減少の傾向を示し，林巴球及び単球には变 動がない，従つて病勢之関係のある血液像に好影㗽 を与えている点もあるが，変動のない点も多く血色 素量等は反つて減少している. 重症で, 赤血球数 及び血色菜量圢減少の煩向で，白血球数化変動なく， 好中球や核左方推移及び淋巴球更に単球等には影響 が㤵められず，依つて病勢と関保のある血液像には 影锌がないが，貫血への傾向は防ぎ得ないるのと考 えられる。

3. 胸部し線写真像に及住寺影響

出性陰影が吸收されたのではないかと思われる 若干例むあつたが，增殖性の陰影や空洞等に対して 


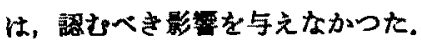

4. 肝機能火及任す影幚

既に第 1 編で述へた様に結核症に於ては，その䏦 機能の各分野に多少共障碍があるのは免れ難い処で あるから，これ等に及ほす Acrifuranの影賠を检討 した.

\section{1）網内系機能}

本機能検查法としては Congored 法を用いたので あるが，岡田31)及び宮城32)に依れば本指数は，病勢 の進行につれて次第に増大し，恢復に赴くに從つて 減少して，遂には機能九進の狀態を示すと言う。ま た宮城は，硬化型から混合型次いで参出型へと，指

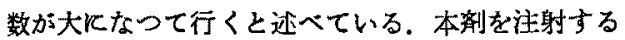
と，軽症で機能減退者が 3 名減り機能六進者が 3 名增加し，中等㱏ては機能隇退者が 3 名と正常者が

第 8 表 Acrifuran 注射に依る Congored 指数の变動

\begin{tabular}{|c|c|c|c|c|c|}
\hline 病 & 型 & 㭘查時期 & 機能六進 & 正 常 & 機能減退 \\
\hline \multirow{2}{*}{ 軽 } & \multirow{2}{*}{ 定 } & 前 & 6 & 2 & \\
\hline & & 後 & 9 & 2 & \\
\hline \multirow{2}{*}{ 中 } & \multirow{2}{*}{ 症 } & 前 & 6 & 10 & \\
\hline & & 後 & 10 & 9 & \\
\hline \multirow{2}{*}{ 重 } & \multirow{2}{*}{ 症 } & 前 & 0 & 2 & \\
\hline & & 後 & 3 & 5 & \\
\hline \multirow{2}{*}{ 合 } & \multirow{2}{*}{ 計 } & 前 & 12 & 14 & \\
\hline & & 後 & 22 & 16 & \\
\hline
\end{tabular}

1 名減つて，譏能六進者汃 4 名增加した，また重症 ては機能減退者の6 名が减り，正常者と譏能六進者 の各 3 名が增加した．従つてこれを綜合的に見ると， 機能減退者が著しく減少して正常者特に機能元進者 が著しく增加し，推計学的にも有意の差として認め られた.

4. 2) 胆汗色絭代謝機能

胆汁色素代謝機能検查飞は血清 Bilirubin 值を测 定したが, Popper 等は血清 Bilirubin の堌加は, 肝細胞の淗漫性障害の程度や Kupfer 星細胞の增殖 等との間に，関連性があると述べている，また結核 症に就いて米田33)や川瀨34)及び篠村36)等は，症狀が 進行するに連れて血清 Bilirubin は低下すると言つ ている. 日本人血清 Bilirubin K就ては井関36)中米 田37)の報告があるが，向井383の発表に従つて男0.23
第9表 Acrifuran 注射に依る血清 Bilirubin の変勤

\begin{tabular}{|c|c|c|c|c|c|}
\hline 病 & 型 & 検查畤期 & 病的减少 & 正 常 & 病的增加 \\
\hline \multirow{2}{*}{ 軽 } & \multirow{2}{*}{ 症 } & 前 & 3 & 10 & 0 \\
\hline & & 後 & 2 & 11 & 0 \\
\hline \multirow{2}{*}{ 中 } & \multirow{2}{*}{ 症 } & 前 & 2 & 22 & 0 \\
\hline & & 後 & 0 & 24 & 0 \\
\hline \multirow{2}{*}{ 重 } & \multirow{2}{*}{ 症 } & 前 & 2 & 15 & 0 \\
\hline & & 後 & 2 & 15 & 0 \\
\hline \multirow{2}{*}{ 合 } & \multirow{2}{*}{ 計 } & 前 & 7 & 47 & 0 \\
\hline & & 後 & 4 & 50 & 0 \\
\hline
\end{tabular}

$\sim 0.84 \mathrm{mg}$ 名及び女子 $0.2 \sim 0.64 \mathrm{mg}$ \%を正常值とし て，以下の样に検討を加えることにした，本剂注射 後軽症では昞的減少者が 1 名減り正常が 1 名增加し， 中等症で病的減少者が 2 名琙り正常が 2 名增加し たが，重症者こは影響はなかつた，従つてこれ管を 綜合的に慁ては，推計学的に有囦の差を生じたとは 思われない。

\section{3）蛋白代謝機能}

蛋白代謝機能検査としては，血清高田反応を行つ

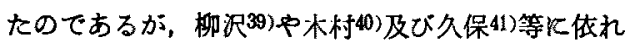
ぼ，本反応が晹性から陰性に転向するのは，肺結核 患者飞於て症狀の轻快を意味し，陰性より陽性への 的向は，增覀を演味すると述べている，本剂注射後 は轻症に於て，㨁陽性者 1 名と中等度陽性者 3 名及 び疑踶性者の 3 名が減少し，搦陽性者の 2 名と陰性 者の 5 名が增加した，また中等症で，強陽性者の 2 名と中等度陽性者の 5 名が減少し，弱陽性者の 1

第10表 Acrifuran 注射に依る高田反心の変動

\begin{tabular}{|c|c|c|c|c|c|c|c|}
\hline 病型 & 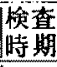 & 陰性 & 疑陽性 & 弱陽 & 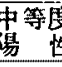 & 強陽性 & 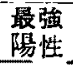 \\
\hline \multirow{2}{*}{ 怪 症 } & 前 & 0 & 7 & 2 & 3 & 1 & 0 \\
\hline & 後 & 5 & 4 & 4 & 0 & 0 & 0 \\
\hline \multirow{2}{*}{ 中等症 } & 前 & 3 & 4 & 3 & 10 & 4 & 1 \\
\hline & 後 & 5 & 8 & 4 & 5 & 2 & 1 \\
\hline \multirow{2}{*}{ 重 症 } & 前 & 2 & 1 & 2 & 2 & 3 & 7 \\
\hline & 後 & 3 & 1 & 2 & 2 & 2 & 7 \\
\hline \multirow{2}{*}{ 合 計 } & 前 & 5 & 12 & 7 & 15 & 8 & 8 \\
\hline & 後 & 13 & 13 & 10 & 7 & 4 & 8 \\
\hline
\end{tabular}


名と㯋陽性者の 4 名及び陰性者の 2 名が増加したが， 重症には殆ど影響はなかつた，これ等を綜合すると， 強陽性中中等度陽性が減少して，弱䎋性や疑陽性特 に陰性が增加するが，推計学的には有意の差を認め 難い。

\section{4) 異物排泄能}

異物排泄試験には Bromsulphalein 法を行つたが, Popper42) 等依れば本法は，肝細胞の破罗及び肝 循環不全を非常に鋭敏に反映すると言い，㕠田43)や 前原以)及び加勢45)等飞依机活肺結核に於て本法の陽 性率㤝停止性のむのと比へると進行性のものに高 くなると言う，本剂注射後は軽症や中等症及び重症 共、それそれ陽性者が3名減少しそれだけ陰性者が增 加した，乙れ等を綜合すると，推計学的皇有意の 差を生じたと言うことができる.

第11表 Acrifuran 注射飞依る Bromsulphalein 成績の変動

\begin{tabular}{|c|c|c|c|c|}
\hline 病 & 型 & 検查時期 & 陰性 & 陽 \\
\hline \multirow{2}{*}{ 軽 } & \multirow{2}{*}{ 症 } & 前 & 8 & 5 \\
\hline & & 後 & 11 & 2 \\
\hline \multirow{2}{*}{ 中 } & \multirow{2}{*}{ 症 } & 前 & 19 & 6 \\
\hline & & 後 & 22 & 3 \\
\hline \multirow{2}{*}{ 重 } & \multirow{2}{*}{ 症 } & 前 & 12 & 5 \\
\hline & & 後 & 15 & 2 \\
\hline \multirow{2}{*}{ 合 } & \multirow{2}{*}{ 計 } & 前 & 39 & 16 \\
\hline & & 後 & 48 & 7 \\
\hline
\end{tabular}

\section{5）解毒機能}

解䓯機能検查には宮路46)の Phenothiazine 法を用 いたが，結核性疾患に就て岩崎47は，重症になる程 馬尿酸合成試験成辕は低下すると言い，宦本と小野 は Santonin 試験朱は馬尿酸合成試験で, 同漛の成 皘を得たとしている. 本剂注射後軽症では陽性者の 3 名と疑陽者の 1 名が隇少しそれれ伴つて陰性者 が 4 名增加した。 また中等症では，強陽性者の9名 が減少し，陽性者の 5 名と疑陽性者の 3 名及び陰性 者の1名がそれそれ增加した，更に重症では強陽性 者の 5 名が減少し, 陽性者 1 名と疑陽性者 2 名及び 陰性者の 1 名が增加した。 これ等を綜合すると強陽 性者が著しく減少し，陽性及び疑陽性特に陰性者が 可成增加して，推計学的にも有意の差を認めること ができる。
第12 Acrifuran 表注射に依る Phenothiazine 成績の変動

\begin{tabular}{|c|c|c|c|c|c|c|}
\hline 病 & 㤠 & 柣查時期 & 陰性 & 疑陽性 & 陽性 & 強陽性 \\
\hline \multirow{2}{*}{ 軽 } & \multirow{2}{*}{ 症 } & 前 & 3 & 3 & 6 & 1 \\
\hline & & 後 & 7 & 2 & 3 & 1 \\
\hline \multirow{2}{*}{ 中 } & \multirow{2}{*}{ 症 } & 前 & 4 & 0 & 5 & 16 \\
\hline & & 後 & 5 & 3 & 10 & 7 \\
\hline \multirow{2}{*}{ 重 } & \multirow{2}{*}{ 症 } & 前 & 6 & 0 & 1 & 10 \\
\hline & & 後 & 8 & 2 & 2 & 5 \\
\hline \multirow{2}{*}{ 合 } & \multirow{2}{*}{ 壾 } & 前 & 13 & 3 & 12 & 27 \\
\hline & & 後 & 20 & 7 & 15 & 13 \\
\hline
\end{tabular}

4. 6) 棓質代謝機能

糖質代謝機能火は Galactose 負荷実験を行つたの であるがこれと就て結核症では，滰本明等は病单 が広沉で重症なものに屡々障害者を見ると言つてい る. 然し川濑49)や干葉50)等は，本代㛛機能が重症結 核に於ても良く保たれると述へている. 本注射後に 於て軽症及び重症では，陽性者の1名減少し隆性者 の1名が增加したか，中等症には影響はなかつた。 㮸つて推計学的に恃有意の差を認め得なかつた。

第13表 Acrifuran 注射に依る Galactose 成績 の変動

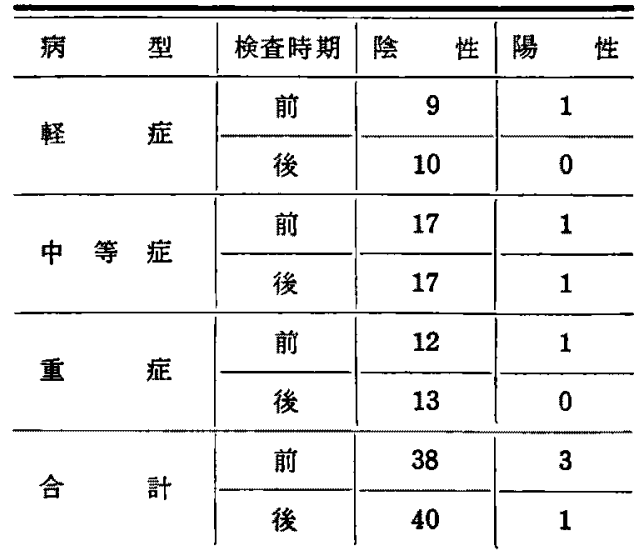

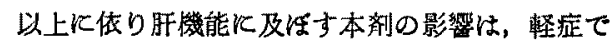
は検討した籍国の全所嘰能改善に有効に作用したと 思われ，中等症では糖代謝以外の，また重症では䏣 汁色素代謝と蛋白代謝以外の腇機能改善に有效で， 而も悪化の傾向に作用した埸合は認められない。 


\section{给括的精按}

3. 6- Diamino - Furfurol-10 - Methyl - Acridium

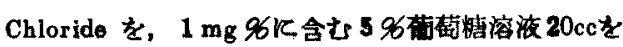

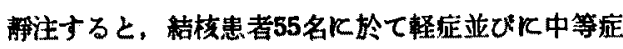
飞著明な自覚症狀の改善る認め，就中気分の好卧と 食照增進は病型の如何を問わず常に現われた，血液 像に站しては，軽症では改善が著明であるが，中等 症では改善と不变が相半ばし，重症では殆ど総て不 変に止つた. 尚中等症及び重症の一部に貝血傾向を 示すものがあつた，既に三浦51)，西海枝，卯尾田及

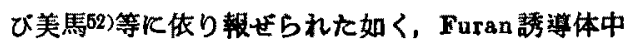
の Nitro-Furan 系のものは結核菌及び陽管細菌に 対し抗菌性を有することがら，Kirchner 培地に本 剂の種々の量を加えこれに結核菌を接種して $37^{\circ} \mathrm{C}$ K3 週間培羡したが，本剂飞依る発青阻止は認めら れずまた本剂の注射が患者喀痰中の結核菌の排出 並びに性狀に影箩を与えることなく，更に䀲部し線 像の改善もはかばかしくないことから，本成の効果 は專ら新陳代謝に関するものと考えられた。依つて

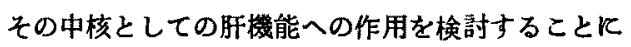
した，結核症に於ける肝瀻の病変としては，脂肪装

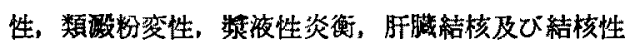
朋硬変等が举げられているが，就中小葉周辺部に起 る脂肪変性は特有のものとされ，Saphir 53)は結核尼 の3496亿勝木54)は朋生検て5296亿認めたと言う. 然 しこれ等の病変が肝機能検査成績にそのままの姿で 反映するるのでないことは，Popper55)等の報告に

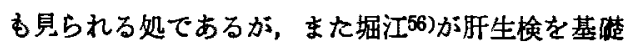

\section{主 要}

1) Mcguigan: J. Pharm. \& Exp. Therap., 21, (1923) 65.

2) Dodd, M. C. \& Stillman, W. B.: J. Pharma. Exp. Therap., 82 (1944), 11.

3) 西海枝: 楽学研究, 20 (1948)， 24.

4) Leitner: Das Blutbild. Bei Tuberculose 結核, 13 (1935), 705 Kょる。

5) 加藤 : 新臨床血液学 (1949)

6) 筒井: 台湾医学会雑誌, 35 (1936), 2859.

7) 小林: 結核, 16 (1938), 762.

8）目金: 結核, 13 (1935), 678.

9) 小宮：臨休血液学 (1952)

10)永井：日新医学，11（1946）, 799.

11) 佐守：日本臨床結核，3 (1942)，115.
Кして解毒及び異物排泄能が犯され易いとするが如 く，何等かの意味て肝线能障害の出現を㒻ることる， 一般に信ぜられている姏てある，依つて本剂注射视 法の前後に於てこれを翻察するに，軽症では実拁し 大籍囲の肝機能に於て，各方向に亘つて，改善が認 められ，中等症では榶代謝を除いて，また重症で忟 䏣汁色素代謝と蛋白代謝を除いて各機能に亘り改善 されるところがあつた，就中全般的に見て解毒㙨能 と網内系機能及び異物排浛機能の改善には，著明な ものが認められた。

\section{喆論}

肺結核患者55名K，3.6-Diamino-Furfurol-10Methyl-Acridium, Chloride $1 \mathrm{mg}$ 名K含を $5 \%$ 葡萄桔溶液 $20 \mathrm{cc}$ を，1 日 1 回 30 日間連続静注し， 以下の栐な結果を得た。

1. 本剂の注射に依り一般に自覚症状を中心とす る諸症状は改善せられ，特に軽症及び中等症に於て 著明であつた.

2. 本剂の血液所見に対する影響では, 軽症に於 ける改善は著明であつたが，中等定では改善と不変 とが相半ばし，重症では不贸が時に䨘血㑯问を示す ものがあつた。

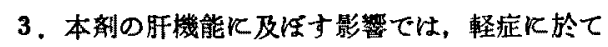
は検討した機能の各方面に亘り，中等症では䊰代謝 機能を除き，また重症では胆汁色素代謝と蛋白梊代 謝を除いて，何れる改善されたが，特に全般的に見 て解䓯機能と網内系機能及び異物排泄僟能に，著し い改善を認められた。

\section{文赫}

12)田中：東京医事新誌，51（1927)， 1475.

13）吉橋：千葉医学会雑誌， 4 (1925), 984.

14) 大閶: 東北医学雑誌, 15 (1933)，607.

15) Grawitz: Deutsch. Med. Woche. Schr., 1893, 51 (1893)

16) Naegeli: Blutkrankheiten. u. Blutdiagnostik. (1931)

17) 早川，岶尾 : 結核， 15 (1937)，592.

18) Arneth: Munch. Med. Wochenschr., 27(1904), 1195.

19) Schwermann \& Appelbaum: Berl. Klin. Wochenscer., I (1902), 7,

20) Hermann: Z. Tbk., 61, (1931), 305.

21) Blumenfeld, Glöel, Stegen: Deutsch. Archf. 
Klin. Med., 98 (1910), 355.

22) 草間：日本内科学会荍誌，4 (1916)，506.

23) 鈴木：結核, 5 (1927)，956,

24）木原：結核， 25 (1955)， 499.

25）山内：結核， 11 (1933), 373.

26) 小山：臨床日本医学, 2 (1933)，1022.

27) Arneth, u. Bergels: Munch. Med. Wochenschr, 27 (1904), 1195.

28) 山内：結核。 17 (1939), 686.

29) Krause: Blutische. Diagnosik, 420 (1913)

30) (5) Kよる.

31）岡田：䜿床病理学血液学雑誌, 4 (1935)， 103.

32）宮城：粘核， 23 (1948)， 64.

33) 米田: 桔核, 15 (1937)， 162.

34) 川湖：消化器病学, 4 (1925), 199.

35）筗村：台湾医学会雑誌，41 (1942), 191.

36) 并関 : 医学研究, 8 (1934), 12.

37) 米田·結核， 13 (1935), 388.

38) 向井 : 医学研究, 22 (1952), 1072.
39) 柳沢：大阪医事新誌，5(1920)，91.

40) 木村：東京医事新誌，2951，2602（1921）

41) 久保：東京医事新誌，2845，2031 (1919)

42) Popper: Am. J. Med., 6 (1949), 278.

43）塞田：名古屋医学会維誌，65 (1951)，302.

44）前原. 結核， 25 (1950)， 503.

45）加然：医缭，6 (1952)， 289.

46) 宮路：岡山医学会雅袐，63 (1951)，81.

47）岩崎：躁床内科小児科，6 (1951)，110.

48) 滰本: 結核, 11 (1919), 944.

49) 川瀨: 消化器病学, 4 (1939), 199.

50) 干葉: 桔核, 24 (1949), 323.

51）三浦：十全医学会雑誌，51 (1948)，273.

52）美馬：J. Amtibiotics, 3 (1950), 809.

53) Saphir, D. Arch. Path., 7 (1929), 1026.

54）勝木：臨床と研究，31 (1954), 341.

55) Popper 等 : J. Lab. Clin. Med., 33 (1948), 435.

56)场江：結核， 27 (1952)， 551.

The First Department of Medicine, Okayama University Medical School

(Director : Prof. K. Yamaoka)

Iwakuni National Hospital

(Director : Dr. M. Watanabe)

Studies on the Effect of Acrifuran on the Liver Function

Part II

The effect of Acrifuran on the liver function of

lungtuberculosis patients.

By

Yasuo KURATA

\section{Conclusions}

I havc given $20 \mathrm{cc}$ of $5 \%$ Glucose with $1 \mathrm{mg} \%$ of 3.6-Diamino-Eurfurol 10-MethylAcridium Chloride intravenously to the 55 patients of lungtuberculosis once a day for 30 days. The results obtained were as follows:

(1) In general, the various symptoms on the subjective symptoms were improved with this medicine especially were remarkable in benign and middle grade cases.

(2) As for the effect of Acrifuran on the blood findings, they were much improved in benign cases, but they were fifty-fifty of improvement and unchangeability in middle grade cases.

In severe cases, they were unchangeable or some of them showad anenicic. 
(3) As for the effect of Acrifuran on the liver function, all of the liver functions in benign cases were improved with Acrifuran. But the function of sugar metabolism in middle grade cases, and of bilirubin metabolism and Albumin metabolism in severe cases remained unimprovable.

In general, Acrifuran gave much improvement on the Antidotal function, the function of reticuloendothelial system and of foreign body exceretion. 